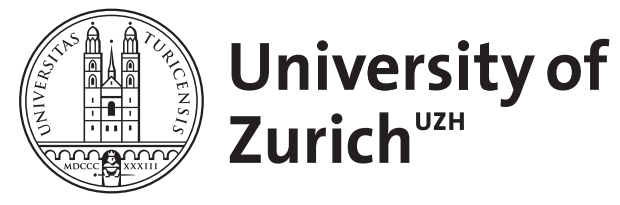

\title{
Renewable energy deployment at the interplay between support policies and
} fossil fuel subsidies

\author{
Zahno, Martina ; Castro Pareja, Paula Monica
}

Posted at the Zurich Open Repository and Archive, University of Zurich

ZORA URL: https://doi.org/10.5167/uzh-143304

Book Section

Accepted Version

Originally published at:

Zahno, Martina; Castro Pareja, Paula Monica (2017). Renewable energy deployment at the interplay between support policies and fossil fuel subsidies. In: Weishaar, Stefan E; Kreiser, Larry; Milne, Janet E; Ashiabor, Hope; Mehling, Michael. The green market transition: carbon taxes, energy subsidies and smart instrument mixes. Cheltenham: Edward Elgar, 97-112. 
Renewable energy deployment at the interplay between support policies and fossil fuel subsidies

$\underline{\text { Martina Zahno }}$ (martina.zahno@pw.uzh.ch $^{1}$

Paula Castro (castro@pw.uzh.ch $)^{1,2}$

${ }^{1}$ Center for Comparative and International Studies (CIS), University of Zurich

${ }^{2}$ Centre for Global Cooperation Research, University of Duisburg-Essen 


\section{Introduction}

Global energy systems face major challenges today. Population growth and accelerated urbanization entail that the rapid increase of the demand for electricity will continue, particularly in developing and emerging countries. At the same time, meeting the ambitious climate mitigation goals established in Paris in December 2015 requires a quick transition away from fossil fuels. In this context, the increased use of renewable energy becomes ever more relevant (Bradshaw 2014; Stadelmann and Castro 2014).

Renewable energy generation grew impressively in the past decade. In 2014, renewables accounted for 85 per cent of the global increase in total power generation (International Energy Agency IEA 2015). However non-conventional renewables (excluding hydro power), on which the focus of this chapter lies, still accounted for only 6 per cent of global electricity production in 2014 (REN21 2015). In the academic debate on how to increase the share of renewable energy, fossil fuel subsidies are an often neglected factor. However such subsidies - particularly popular among governments of developing and emerging countries to shield their populations from high energy prices - result in price distortions that must be expected to affect the markets for renewables, and thus need to be taken into account in any analysis of the effectiveness of the policy mix established to support renewable energy.

Using data from 155 countries between 2003 and 2013, in this chapter we provide the first systematic, cross-country evidence that fossil fuel subsidies are highly likely to present a significant barrier to the deployment of renewable energy, even in the presence of policies that also subsidize or otherwise support renewables. We focus on the generation of electricity from non-conventional renewable energy sources. We intentionally exclude hydropower from the analysis since large hydropower can be considered a traditional and competitive electricity source already and since investment decisions towards large hydro facilities follow a very different rationale than investment in other renewables. 
The remainder of this chapter is structured as follows: Section 7.2 summarizes insights from economic theory and empirics regarding the impact of fossil fuel subsidies. The data and descriptive statistics are presented in Section 7.3, followed by a panel regression model of the determinants of renewable electricity production, with a special focus on the effect of fossil fuel subsidies and policies to support renewables in Section 7.4. The last section concludes our findings.

\section{Undesirable effects of fossil fuel subsidies: insights from economic theory}

Governments across the globe intervene in energy prices. While many countries tax fossil fuels to internalize negative externalities and generate public revenues, others heavily subsidize fossil fuel based energy production or prices. Subsidies for fossil fuels create distortions of resource allocation, reduce total welfare and have a negative impact on the environment (Burniaux and Château 2011; Davis 2014; Plante 2014). Straightforward economic rationale moreover predicts that subsidizing fossil fuels - a close substitute of renewables - leads to reduced demand for and lower production of energy from renewables.

Beyond this direct competition effect, more indirect effects are likely. The position of fossil fuels in the power supply system could further be reinforced by an 'incumbent advantage' created by fuel subsidies. For instance, a slowdown of renewables deployment may lead to a decline in learning rates and the associated cost reductions. Moreover, fossil fuel subsidies may drain financial resources away from investments in low carbon infrastructure (Whitley 2013).

Investment in renewable electricity capacities relies on subsidies or other support schemes to ensure market entry. For this reason, it has been argued that lower prices for other fuels used in power generation may increase the costs of subsidy schemes for renewables. However according to the IEA (2015) incentives to invest in renewables would persist unless a change in policy is forced. In contrast, evidence from selected countries suggests that government expenditures in fossil fuel subsidies may crowd out public support for renewable technologies directly (Meier et al. 2014). We hence argue that persistent crowding out effects on renewable energy support schemes are likely in the case of fuel subsidies. 
Overall, we expect fossil fuel subsidies to matter for the deployment of renewables, beyond the effect of domestic support schemes for renewable energy. For this reason, we argue that it is critical to consider fossil fuel subsidies as part of the relevant policy mix when assessing the effectiveness of renewable energy support schemes.

Empirically, only a few studies address the potentially negative effect of fossil fuel subsidies on renewables. Case studies in Middle-Eastern and North African countries illustrate how the relative cost advantage of wind and solar technologies due to favourable climatic conditions is thwarted by fossil fuel subsidies (Bridle et al. 2014). Schmidt et al. (2012) show that the cost differential between renewable energy and conventional technologies varies largely across specific country-technology combinations, so that fossil fuel subsidies have a leverage effect if there is a relatively small cost differential between renewables and the unsubsidized baseline.

In this chapter we add a macro perspective to the existing evidence, showing that across countries, higher levels of fossil fuel subsidies go along with a lower contribution of renewables to power generation, even after major determinants of renewable energy generation are controlled for.

\section{Data: Renewable electricity and fossil fuel subsidies}

Share of Electricity from Non-conventional Renewables

Our dependent variable is the share of net electric power generated from non-conventional renewables including geothermal, solar, tide and wave, wind, biomass and renewable waste. Data is obtained from the US Energy Information Administration (EIA 2016). Hydropower is intentionally excluded for the reasons stated above. ${ }^{1}$ Modern renewable electricity is not yet widespread in most countries. In the last few years its share has only surpassed 30 per cent in Denmark, Germany and Nicaragua. The clearest upward tendency can be recognized among the advanced economies, but renewables are also on the rise in emerging countries. Across lowincome countries, the development has been ambiguous but with a strong upward trend starting 
in 2012. Nonetheless, non-conventional renewables are still non-existent in 37 out of the 57 low-income countries included in the sample.

Fossil Fuel Subsidies

Energy subsidies are broadly defined by the IEA (2010) as '[...] any government action that lowers the cost of energy production, raises the revenues of energy producers or lowers the price paid by energy consumers'. The systematic collection of data on the extent and volume of subsidies on fossil fuels presents a challenge that has only recently been taken up. We use country-level subsidy estimates drawn from a dataset compiled by International Monetary Fund (IMF) staff, which is the most complete and comparable data currently available (Coady et al. 2015; IMF 2015) We use the so-called pre-tax subsidy estimates, which do not include the negative external costs from the combustion of fossil fuels. We focus on consumer subsidies for gasoline, diesel, coal and natural gas, for both households and firms (like electric utilities or industry). ${ }^{2}$

Bivariate Relationship between Fossil Fuel Subsidies and Renewable Electricity Share

First insights on the potential relationship between the share of renewables and fossil fuel subsidization can be gained from plotting the two variables, as shown in Figure 7.1. 
Figure 1: Share of electricity from renewables and fossil fuel subsidies in $2013^{1}$

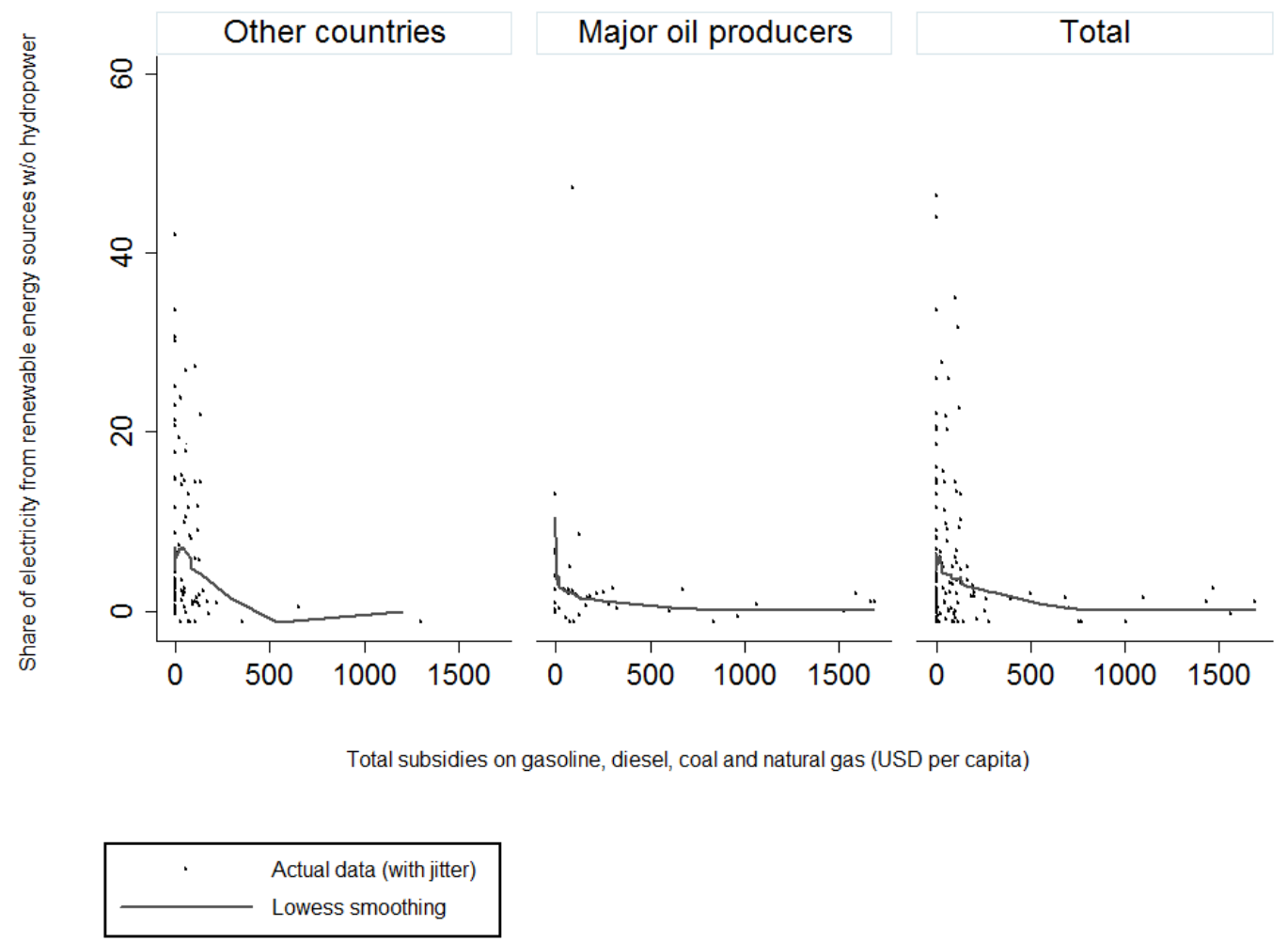

Across all observations, the data broadly supports the hypothesis that higher fuel subsidies tend to go along with lower shares of renewable electricity. A linear relationship is not recognizable. It can however be stated that the vast majority of countries with high fossil fuel subsidies have very low shares of renewables in their power mix (lower than 5 per cent). Simultaneously, basically all countries with a significant contribution of renewables do not or only marginally subsidize fossil fuels.

The separate plots for major oil producers as compared to other countries illustrate how the subsidization of fossil fuels is particularly prevalent in oil producing countries. Moreover, limiting the group of oil producers to OPEC countries would indeed leave us with a share of renewables that is close to zero. However including all 30 top oil producing countries shows that there is substantial variation in the degree of subsidization as well as renewables participation even within this group. Alternative plots using data from emerging and developing

\footnotetext{
${ }^{1}$ Data for 132 countries in 2013. International Energy Statistics data from EIA (2016), data on subsidies from IMF (2015), data on population from World Development Indicators (World Bank 2016).
} 
countries show comparable results, indicating that the relationship is not driven by the high shares of renewables in advanced economies.

\section{Multivariate regression analysis}

In this section we test the negative relationship between fossil fuel subsidies and the share of renewable electricity with a full panel regression model on the determinants of electricity generation from renewables. Apart from fossil fuel subsidies, a special focus lies on the role of renewable electricity support policies. As explained above, in most cases the installation of modern renewable electricity capacities still relies on financial support. We are thus interested in how such financial support affects the deployment of renewable electricity after accounting for the hypothesized detrimental effect of fossil fuel subsidies. Given that there is no data on the actual magnitude of financial incentives for renewables, we proxy such support through a count variable for a range of country-level policies providing financial support to grid-based renewable electricity production, including feed-in tariffs, other financial incentives such as tax exemptions or reductions, public investments and renewable energy tenders. ${ }^{3}$ Data from Stadelmann and Castro (2014) serves as a basis and is completed for advanced economies and updated using data from REN21 (2015) and the Global Renewable Energy policies and measures database (IEA/IRENA 2016).

\section{Estimation Method}

Given the small variation of our dependent variable - the contribution of non-conventional renewables to electricity supply - over time and the fact that the available data covers a 10 -year time period only, the slow transition towards renewable energy is not reflected very well. As a consequence, the role of fuel subsidies is analysed with a main focus on exploring the variation between countries. For this reason, and because we believe that it is profoundly important to our research question to understand and model the role of country context explicitly, we opt for a random effects specification that allows us to analyse and separate both the within and between 
country effects explicitly. The general model, referred to as the 'within-between' formulation by Bell and Jones (2015), and the 'hybrid' solution by Allison (2009) is given by:

$Y_{i t}=\beta_{0}+\beta_{1}\left(x_{i t}-\bar{x}_{i}\right)+\beta_{2} c_{i}+\beta_{3} \bar{x}_{i}+\mu_{i}+\varepsilon_{i t}$

where $x_{i t}$ is a variable that varies between and within countries, and $c_{i}$ is a variable that varies only between countries. $\mu_{i}$ is the between-country error and the random intercept, and $\varepsilon_{i t}$ is the between and within error. Country-specific means of $x_{i t}$ and deviation scores (also referred to as group mean centering) are generated before fitting the hybrid model with panel randomeffects estimation. $\beta_{1}$ corresponds to the within estimate (identical to the fixed-effect estimate), and $\beta_{3}$ estimates the between effect. ${ }^{4}$

Due to strong autocorrelation in the dependent variable, we include year fixed effects that should account for broad trends such as technological change and the associated cost reductions as well as international fuel prices or global economic developments. In addition, we account for grouping of the observations on the country level by using country-clustered standard errors wherever allowed by the statistical model.

We apply a two-part model in logs to account for the censored data structure and the large proportion of zeros in the dependent variable. This allows for the possibility that the zero and positive values are generated by different mechanisms, that is, affected by different sets of variables or affected differently by the same variables.

Our modelling strategy hence combines two parts: For the first part we apply randomeffect probit models to predict the likelihood that country $i$ generates a positive amount of electricity from non-conventional renewables in year $t$. The second part, containing positive values for $y$, is transformed to logs. We then estimate linear random-effect models with clustered standard errors. In both cases, we decompose the within and between effects as outlined above. 
Determinants of Renewable Electricity Generation

We control for further variables that the existing literature has found to be relevant (Aguirre and Ibikunle 2014; Marques et al. 2019; Popp et al. 2011; Sadorsky 2009a, b).

High-income countries have a better capacity to invest in renewable electricity. The environmental Kuznets curve theory further suggests that while in the early stages of economic development, material well-being is valued more than environmental amenities, citizens pay greater attention to the environment once a sufficiently high standard of living is attained (Arrow et al. 1995). We hence add a control for the log of GDP per capita in constant purchasing power parity terms (constant 2011 international USD). The data is obtained from the World Development Indicators (WDI) (World Bank 2016). The argument above however holds only to the extent to which policies reflect people's preferences. In democracies the population's preferences (including those for a clean environment) are better represented. More generally, democratic regimes are more responsive to the demand for public goods than authoritarian regimes (Bueno de Mesquita et al. 1999). Based on this rationale we control for the level of democracy using the Freedom House 'polity' indicator (Freedom House 2015). ${ }^{5}$

The cost of renewable electricity depends crucially on the local availability of the corresponding resources. We thus include a variable that aggregates the country-level technical potential for energy production from different renewables (including solar, geothermal, on- and offshore wind, and sugar crops and livestock manure as proxies for biomass potential), estimated by World Bank staff (Buys et al. 2009).

We additionally account for the energy consumption of a country - which should affect demand for renewables - by including the logged total primary energy consumption, with data obtained from the IEA (2016).

Electricity supply from renewables is also related to energy security concerns. The literature suggests that the deployment of renewables is incentivized by the aim to substitute energy imports with locally produced energy (Gan et al. 2007). We calculate the dependence on energy imports by taking the difference between countries' total energy exports and total energy 
imports and expressing it as a share of their total energy consumption. ${ }^{6}$ The data is from EIA (2016).

Environmental concerns can be expected to simultaneously affect the share of renewables and fossil fuel subsidies. As a measure for countries' efforts in promoting environmental quality we use an adapted version of the Environmental Performance Index (2014). ${ }^{7}$ We excluded two categories of components from the composite index: first, measures of environmental stresses on human health, as they are strongly poverty related (e.g. access to drinking water and sanitation or child mortality) and second, climate policy indicators such as $\mathrm{CO}_{2}$ emission intensity, which would be good controls for a country's level of responsibility towards climate change, but can cause a problem of reverse causality. ${ }^{8}$

The presence of oil and gas resources is another relevant factor. Major oil producers tend to support the domestic oil industry and hold domestic fuel prices low. This structural bias can be expected to have a negative impact on the support of renewables deployment. However from a long-term perspective, volatile global oil prices might also incentivize investments into alternative domestic energy supply in order to free oil resources for exports. ${ }^{9}$ Major oil producing countries also generally face comparatively lower financial constraints with regards to support for new renewable energy infrastructure. Hence, effects in both directions are plausible. We thus include a dummy for members of the Organization of the Petroleum Exporting Countries (OPEC) as an indicator for oil-producing countries in our model.

Results

Tables 7.1 and 7.2 present the results of our main two-part regressions for different model specifications in the binary and the positive part respectively. Table 7.1 shows that fossil fuel subsidies do not seem to be related in a significant and robust way to the likelihood that a country produces renewable electricity. In contrast, the coefficients for renewable energy support policies are significantly positive across different specifications in the between part of the regression. Renewable energy support policies thus seem to be a critical condition for setting 
the initial stage of producing renewable electricity, even though no significant effects stem from within-country increases in the number of support policies over time.

Table 1: Regression results for the likelihood that a country produces renewable electricity at all

(1)

(1)

(2)

(3)

(4)

$(5)$

(6)

WITHIN COUNTRY EFFECTS

FF subsidies per capita $(\log )$

$-0.02$

$(0.15)$

0.03

(2.37)

GDP per capita $(\log )$

RE policies

Democracy

Environmental performance

$-0.19$

$(0.38)$

0.34

$(0.38)$

$-0.15$

(0.17)

Energy consumption (log)

Net energy imports share

\section{BETWEEN COUNTRY EFFECTS}

FF subsidies per capita (log)

0.12

$$
\text { (0.19) }
$$

$-0.13$

0.19

$(0.28)$

GDP per capita $(\log )$

$(0.45)$

RE potential

$0.03 * * * \quad 0.01$

$(0.01) \quad(0.01)$

RE policies

Democracy

$5.77 * * 4$

$(0.60)$

0.03

$(0.20)$

Environmental performance

0.12

$(0.05)$

$-9.47$

(2.00)

$(0.01)$

-0.05
$(0.24)$

$-1.88$

(4.15)

$-0.23$

$(0.66)$

0.51

$(0.55)$

0.02

$(0.24)$

5.15

(2.79)

OPEC

Energy consumption $(\log )$

(1.58)

0.66

$(0.27)$

0.18

(0.09)

$-16.35$

(3.29)

3.47

$(0.51)$

Net energy imports share

Constant

$\begin{array}{lll}-7.34 & * * & 0.17\end{array}$

(3.67)

(7.45)

1,392

1,392

155

YES

YES

$-136.3$
$-0.04$

(0.14)

$-0.05$

(2.35)

$-0.17$

(0.37)

0.26

(0.38)

$-0.14$

(0.17)$$
\text { * }
$$

0.00

(0.00)

-0.03
$(0.13)$
0.24
$(2.25)$
-0.16
$(0.37)$
0.33
$(0.32)$

$-0.05$

$-0.04$

(0.13)

(0.13)

$-1.31$

0.39

(2.59)

(2.36)

$-0.07$

$-0.18$

(0.41)

(0.37)

0.31

0.34

(0.37)

(0.34)

$-0.17$

$-0.07$

$-0.16$

(0.17)

(0.18)

(0.18)

3.13

0.00

(0.00)

\subsection{8}

(0.15)

0.33

$(0.51)$

0.03

0.03

(0.01)

-0.05
$(0.12)$
0.02

$-0.18$

$-0.02$

0.02

(0.16)

(0.16)

$(0.37)$

$-1.06$

$(0.48)$

** $\quad 0.28$

$0.02 \quad * * \quad 0.01$

$(0.47)$

$(0.01)$

(0.01)

0.02

$(0.01)$

5.39
$(0.64)$

$5.79 *$

4.17

5.55

0.00

$(0.53)$

(1.00)

$(0.62)$

$(0.22)$

0.08

0.45

$(0.20)$

** $\quad 0.00$

$(0.15)$

(0.19)

** 0.12

$(0.05)$

$-8.31$

(1.69)

(0.04)

$(0.03)$

0.11

(0.04)

$$
\begin{array}{r}
1.70 * * * \\
(0.43)
\end{array}
$$

$0.00 * * *$ $(0.00)$

$-8.21$

(4.03)$$
\text { (3) }
$$

(3.96)

1,392

155

YES

1,392

155

YES

$-152.5$

$-158.6$

55
ES
8.6

\begin{tabular}{rrr} 
& & 0.00 \\
& & $(0.00)$ \\
-6.13 & $* *$ & 2.07 \\
$(2.97)$ & & $(4.22)$ \\
& & \\
\hline 1,392 & & 1,392 \\
155 & & 155 \\
YES & & YES \\
-151.7 & & -157.1
\end{tabular}

Note: Results are from regressions on a dummy variable indicating whether a country has renewable electricity at all or not, using a random effects probit model with decomposed within and between effects. Standard errors in parentheses. Stars indicate the statistical significance: $*=$ p-value $<0.1,{ }^{* *}=$ p-value $<0.05, * * *=$ p-value $<0.01$. FF stands for fossil fuels, RE for renewable energy. 
The effects of the control variables are generally as expected, and are observed mainly at the between-country level. Higher energy consumption and energy dependence, a higher potential for renewables and environmental concern are related to a significantly higher probability to generate renewable electricity. For the OPEC dummy, we find a highly significant negative effect on countries' likelihood to invest in renewable electricity. This result supports the hypothesis that fuel-based economies are far from a transition towards higher shares of renewables.

Robustness checks (available on request), where the year dummies were replaced by international fuel prices or by fuel prices and a year trend, did not affect our other results substantively. The same is true if we limit the sample to low-income and emerging economies. Additionally, we restricted the sample to those countries with the highest variation in subsidies along the time period observed, corresponding to the highest 50,60 or 70 percentiles. We used simple random-effect probit models in these subsamples to explore whether there is any significant within-country effect of fossil fuel subsidies in the countries in which this is most likely. And as a final robustness check, we collapsed our sample into two time periods, 2003-07 and 2008-12, and took the means of all variables for each country in those time periods. The rationale behind this is to model the longer-term effects, given the slow rate of change in the dependent variable. In both robustness checks, we find again insignificant effects of fossil fuel subsidies and positive effects of renewable energy support policies on the likelihood that countries invest in renewable electricity.

The results regarding the amount of renewable electricity generated are displayed in Table 7.2. In this case, fuel subsidies are as expected negatively related to the share of renewable electricity when they are compared across countries. But again, within countries we do not have any significant effects. A similar conclusion can be drawn with regards to financial support policies for renewables: while changes over time do not seem to play a significant role within countries, they are positively related to the share of renewable electricity generation when compared across countries. 
Table 2: Regression results for the amount of renewable electricity produced

\begin{tabular}{|c|c|c|c|c|c|c|c|c|}
\hline & (7) & & $(8)$ & & (9) & & (10) & \\
\hline \multicolumn{9}{|l|}{ WITHIN COUNTRY EFFECTS } \\
\hline FF subsidies per capita $(\log )$ & $\begin{array}{r}-0.01 \\
(0.02)\end{array}$ & & $\begin{array}{r}-0.01 \\
(0.018)\end{array}$ & & $\begin{array}{c}-0.01 \\
(0.02)\end{array}$ & & $\begin{array}{r}0.00 \\
(0.016)\end{array}$ & \\
\hline GDP per capita $(\log )$ & $\begin{array}{r}1.53 \\
(0.73)\end{array}$ & $* *$ & $\begin{array}{r}2.84 \\
(0.93)\end{array}$ & $* * *$ & $\begin{array}{r}1.40 \\
(0.75)\end{array}$ & $*$ & $\begin{array}{r}2.82 \\
(0.91)\end{array}$ & $* * *$ \\
\hline RE policies & $\begin{array}{r}0.06 \\
(0.09)\end{array}$ & & $\begin{array}{r}0.05 \\
(0.09)\end{array}$ & & $\begin{array}{r}0.05 \\
(0.09)\end{array}$ & & $\begin{array}{r}0.07 \\
(0.09)\end{array}$ & \\
\hline Democracy & $\begin{array}{r}0.05 \\
(0.07)\end{array}$ & & $\begin{array}{r}0.09 \\
(0.07)\end{array}$ & & $\begin{array}{r}0.06 \\
(0.07)\end{array}$ & & $\begin{array}{r}0.09 \\
(0.08)\end{array}$ & \\
\hline Environmental performance & $\begin{array}{r}0.11 \\
(0.05)\end{array}$ & $* *$ & $\begin{array}{r}0.08 \\
(0.04)\end{array}$ & $*$ & $\begin{array}{r}0.11 \\
(0.05)\end{array}$ & $* *$ & $\begin{array}{r}0.06 \\
(0.04)\end{array}$ & \\
\hline Energy consumption (log) & & & $\begin{array}{r}-1.65 \\
(0.552)\end{array}$ & $* * *$ & & & $\begin{array}{r}-1.72 \\
(0.587)\end{array}$ & $* * *$ \\
\hline Net energy imports share & & & & & $\begin{array}{r}0.00 \\
(0.00)\end{array}$ & $* *$ & & \\
\hline Nuclear electricity share & & & & & & & $\begin{array}{l}-0.02 * \\
(0.01)\end{array}$ & \\
\hline Hydro electricity share & & & & & & & $\begin{array}{l}-0.01 \\
(0.01)\end{array}$ & \\
\hline \multicolumn{9}{|c|}{ BETWEEN COUNTRY EFFECTS } \\
\hline FF subsidies per capita (log) & $\begin{array}{c}-0.12 \\
(0.05)\end{array}$ & $* *$ & $\begin{array}{r}-0.10 \\
(0.05)\end{array}$ & $* *$ & $\begin{array}{c}-0.12 \\
(0.05)\end{array}$ & $* *$ & $\begin{array}{r}-0.09 \\
(0.05)\end{array}$ & $*$ \\
\hline GDP per capita $(\log )$ & $\begin{array}{r}-0.82 \\
(0.29)\end{array}$ & $* * *$ & $\begin{array}{c}-0.72 \\
(0.30)\end{array}$ & $* *$ & $\begin{array}{c}-0.83 \\
(0.30)\end{array}$ & $* * *$ & $\begin{array}{c}-0.75 \\
(0.31)\end{array}$ & $* *$ \\
\hline RE potential & $\begin{array}{r}0.00 \\
(0.00)\end{array}$ & $*$ & $\begin{array}{r}0.00 \\
(0.00)\end{array}$ & $*$ & $\begin{array}{r}0.00 \\
(0.00)\end{array}$ & $*$ & $\begin{array}{r}0.00 \\
(0.00)\end{array}$ & \\
\hline RE policies & $\begin{array}{r}0.37 \\
(0.20)\end{array}$ & $*$ & $\begin{array}{r}0.46 \\
(0.22)\end{array}$ & $* *$ & $\begin{array}{r}0.39 \\
(0.21)\end{array}$ & $*$ & $\begin{array}{r}0.69 \\
(0.24)\end{array}$ & $* * *$ \\
\hline Democracy & $\begin{array}{r}0.28 \\
(0.09)\end{array}$ & $* * *$ & $\begin{array}{r}0.27 \\
(0.09)\end{array}$ & $* * *$ & $\begin{array}{r}0.28 \\
(0.09)\end{array}$ & $* * *$ & $\begin{array}{r}0.22 \\
(0.09)\end{array}$ & $* *$ \\
\hline Environmental performance & $\begin{array}{r}0.06 \\
(0.02)\end{array}$ & $* * *$ & $\begin{array}{r}0.06 \\
(0.02)\end{array}$ & $* *$ & $\begin{array}{r}0.06 \\
(0.02)\end{array}$ & $* * *$ & $\begin{array}{r}0.06 \\
(0.02)\end{array}$ & $* * *$ \\
\hline OPEC & $\begin{array}{r}-0.87 \\
(1.17)\end{array}$ & & $\begin{array}{r}-0.68 \\
(1.13)\end{array}$ & & $\begin{array}{r}-0.87 \\
(1.16)\end{array}$ & & $\begin{array}{r}-0.94 \\
(1.10)\end{array}$ & \\
\hline Energy consumption (log) & & & $\begin{array}{r}-0.13 \\
(0.14)\end{array}$ & & & & $\begin{array}{r}-0.07 \\
(0.14)\end{array}$ & \\
\hline Net energy imports share & & & & & $\begin{array}{r}0.00 \\
(0.00)\end{array}$ & & & \\
\hline Nuclear electricity share & & & & & & & $\begin{array}{c}-0.01 \\
(0.01)\end{array}$ & \\
\hline Hydro electricity share & & & & & & & $\begin{array}{r}0.01 \\
(0.01)\end{array}$ & \\
\hline Constant & $\begin{array}{r}13.75 \\
(1.81)\end{array}$ & $* * *$ & $\begin{array}{l}12.84 \\
(2.02)\end{array}$ & $* * *$ & $\begin{array}{r}13.85 \\
(1.89)\end{array}$ & $* * *$ & $\begin{array}{r}12.79 \\
(2.02)\end{array}$ & $* * *$ \\
\hline Observations & 853 & & 853 & & 853 & & 816 & \\
\hline Number of countries & 100 & & 100 & & 100 & & 95 & \\
\hline Year dummies & YES & & YES & & YES & & YES & \\
\hline $\mathrm{R} 2$ overall & 0.29 & & 0.30 & & 0.29 & & 0.34 & \\
\hline
\end{tabular}


$\begin{array}{lllll}\mathrm{R} 2 \text { between } & 0.36 & 0.37 & 0.36 & 0.42\end{array}$

$\begin{array}{lllll}\text { R2 within } & 0.29 & 0.32 & 0.30 & 0.34\end{array}$

Note: Results are from regressions on the log-transformed positive values of renewable electricity share, using a standard random-effects linear panel with decomposed within and between effects. Country-clustered standard errors in parentheses. Stars indicate the statistical significance: $*=$ p-value $<0.1, * *=$ p-value $<0.05, * * *=$ p-value $<0.01$. FF stands for fossil fuels, RE for renewable energy.

Again, the coefficients for most control variables are as expected. Democratic institutions turn out to be a significant driver of cross-country differences in renewables deployment in this development stage, while our control for OPEC membership is insignificant, which is however not completely surprising because most OPEC members simply do not have any renewable electricity in the time period analysed.

Somewhat surprisingly, increased per capita income is positively related to renewables within a single country across time, while across countries, higher GDP levels tend to relate to lower shares of renewables. This finding holds if we exclude advanced economies from the sample. As additional controls we tested the share of nuclear and hydropower in the electricity mix. Negative effects can be expected, because once built, nuclear and large hydropower plants generate electricity at low marginal costs, thus acting as low-cost competitors to renewables, even though the initial investment costs were high. ${ }^{10}$ We find that within countries, both energy sources are consistently negatively related to the share of modern renewables, while betweeneffects are insignificant. This would suggest that there is a trade-off between different fossil-free power generation technologies; the effects are very small though. A smaller contribution of modern renewables is also related to increased total energy use within the same country.

We ran similar robustness tests as for the binary part (all results on request). Limiting the sample to low-income and emerging economies weakened our findings but does not affect the direction of the effects. Restricting the sample to those countries that have more variation in the subsidies provides us with some interesting new insights. We discovered the expected negative coefficient for fossil fuel subsidies when looking at the within-country effects. It seems that when looking at the relevant countries, we do find that within a country, higher subsidies are related to less renewable energy deployment (or vice versa). But for these subsamples, the more general cross-country tendency that we observed in the general models in Table 7.2 is reversed: when comparing across the countries with highest variability in fossil fuel 
subsidization, higher fossil fuel subsidies are related to a higher share of renewables. These results become stronger the higher the chosen threshold for the fossil fuel subsidies differential. In all models, the support policies for renewables are positively related to renewable electricity share when comparing across countries. After collapsing our dataset into averages for the time periods 2003-07 and 2008-12 we also obtain results that support our expectations.

\section{Conclusions}

Using a comprehensive cross-country dataset over 10 years, we assessed whether fossil fuel subsidization presents a barrier to the deployment of non-conventional renewable energy, while taking into account financial support policies for renewables.

Our main results indicated that the effects of fossil fuel subsidies and of subsidies for renewables differ between the two stages of the deployment of renewables, analysed separately in this chapter: we found that the likelihood that a country produces any electricity from renewables does not seem to be related to fossil fuel subsidies. Rather, other higher-level factors are found to be relevant in this initial stage, namely the reliance of a country's economy on oil production, its potential for renewables compared to other countries, financial support policies for the deployment of renewables and the general environmental performance.

In cases where countries already produce grid-based electricity from renewables, higher levels of fossil fuel subsidies tend to go along with lower renewable electricity shares, while subsidies and other financially supportive measures for renewables seem to be positively linked to their contribution to total power generation. However only the between-country component of the variables is significant, owing to the rather short time period covered and the dominance of country-level differences over differences over time for both policy measures.

While our study provides first cross-country indications of the adverse consequences of fossil fuel subsidization on renewable electricity provision, further research is required to strengthen the evidence and to provide insights into causal mechanisms on the country level. Nevertheless, we can conclude as a policy-relevant insight that efforts to reform fossil fuel 
subsidies and redirect public expenditures to investments in non-conventional renewable technologies can be expected to benefit the further dissemination of renewable energy.

${ }^{1}$ Missing values for 2013 are imputed using IEA (2016).

${ }^{2}$ Consumer subsidies are estimated using the so-called price gap approach, which basically compares end-user prices with a reference price, given by the full cost of supply. The total value of fossil fuel subsidies for a given country corresponds to the aggregated size of the price gap for each fuel in each sector, multiplied by the volume consumed. We exclude producer subsidies from our analysis as this data is incomplete across the whole country sample. However their size is comparatively small compared to the consumer subsidies, so we do not expect this omission to be too problematic.

${ }^{3}$ Softer support measures, such as framework policies for renewables or renewable energy targets were excluded from the regressions shown here, as we do not expect them to be that relevant. However robustness tests with a variable that counted all existing support policies did not alter our results significantly.

${ }^{4}$ The model is different from a correlated random effects model as first proposed by Mundlak (1978), in which the estimated effect of $\bar{x}$ is not the between effect, but the difference between $\beta_{1}$ and $\beta_{3}$. See also Schunck (2013).

${ }^{5}$ Data retrieved from the Quality of Government Dataset, by Teorell et al. (2016). In addition, government effectiveness is an important precondition for any investments in a country. We thus tried controlling for government effectiveness using data from the Worldwide Governance Indicators in robustness checks, but its effect is unclear given the strong correlation with income and democracy. See Kraay et al. (2010).

${ }^{6}$ Following Marques et al. (2010).

${ }^{7}$ For the methodology of the Environmental Performance Index see Esty et al. (2008). 
${ }^{8}$ While we expect that countries with higher emissions should have a higher incentive to deploy renewables, at the same time increasing renewables reduces emissions. Robustness checks with the complete Environmental Performance Index or with a dummy indicating time of Kyoto Protocol ratification as a more direct control for concerns regarding climate change did not change our findings.

${ }^{9}$ This is apparently the case in a number of countries in the Middle East, one of the few regions where oil is still widely used in the power sector; the sharp fall in oil prices in recent years has led to efforts to reduce domestic oil demand and to replace parts of the fuel-based power generation by renewables according to the Guardian (2016).

${ }^{10}$ In addition, nuclear and hydro power reduce countries' energy dependency, which is one of the reasons for investing in renewables. Data on the share of nuclear and hydro power from all net power generation stems from the World Bank World Development Indicators.

\section{References}

Aguirre, M. and G. Ibikunle (2014), 'Determinants of renewable energy growth: A global sample analysis', Energy Policy, 69, 374-384.

Allison, P.D. (2009), Fixed effects regression models, Los Angeles, SAGE.

Bell, A. and K. Jones (2015), 'Explaining fixed effects: random effects modeling of time-series cross-sectional and panel data', Political Science Research and Methods, 3:1, 133-153.

Arrow, K., B. Bolin, R. Costanza, P. Dasgupta, .C. Folke, C.S. Holling, B.-O. Jansson, K.-G. Maler, C. Perrings, and D. Pimentel (1995), 'Economic growth, carrying capacity, and the environment', Ecological Economics, 15, 91-95. 
Bueno De Mesquita, B, J.D. Morrow, R.M. Siverson and A. Smith (1999), 'Policy failure and political survival: The contribution of political institutions', Journal of Conflict Resolution, 43:2, 147-61.

Bradshaw, M.J. (2014), Global energy dilemmas: Energy security, globalization, and climate change, Polity, Cambridge: Wiley.

Bridle, R., L. Kiston and P. Wooders (2014), Fossil-fuel subsidies: A barrier to renewable energy in five Middle East and North African countries, IISD, Winnipeg.

Burniaux, J.-M. and J. Château (2011), Mitigation potential of removing fossil fuel subsidies: A general equilibrium assessment, OECD Economics Department Working Papers, No. 853, Paris: OECD Publishing.

Buys, P., U. Deichmann, C. Meisner, T. Ton That and D. Wheeler (2009), 'Country stakes in climate change negotiations: Two dimensions of vulnerability', Climate Policy, 9:3, 288 305.

Coady, D., I. Parry, L. Sears and B. Shang (2015), How large are global energy subsidies? IMF Working Paper No. 15/105.

Davis, L.W. (2014), 'The economic cost of global fuel subsidies', American Economic Review, 104:5, 581-585.

Esty, D.C., M.A. Levy, C.H. Kim, A. de Sherbinin, T. Srebotnjak and V. Mara (2008), 'Environmental performance index', New Haven: Yale Center for Environmental Law and Policy, 382, www.epi.yale.edu, accessed 28 December 2016.

Freedom House (2015), Freedom in the world: Aggregate and subcategory scores, https://freedomhouse.org/report/freedom-world-aggregate-and-subcategory-scores.

Gan, L., G.S. Eskeland, and H.H. Kolshus (2007), ‘Green electricity market development: Lessons from Europe and the US', Energy Policy, 35:1, 144-155. 
International Monetary Fund (2015), Counting the cost of energy subsidies: IMF Survey, www.imf.org/external/pubs/ft/survey/so/2015/NEW070215A.htm, accessed 13 May 2016. International Energy Agency (2010), World Energy Outlook 2010, Paris: OECD/IEA. International Energy Agency (2015), World Energy Outlook 2015, Paris: OECD/IEA. International Energy Agency (2016), IEA world renewable and waste energy supply, www.oecd-ilibrary.org/energy/data/iea-renewables-information-statistics, accessed 26 April 2016.

International Energy Agency/IRENA (2016), Global renewable energy: Joint policies and measures database, www.iea.org/policiesandmeasures/renewableenergy, accessed 27 April 2016.

Kitson, L. and R. Bridle (2014), The impact of fossil-fuel subsidies on renewable electricity generation, IISD, Winnipeg.

Kraay, A., D. Kaufmann and M. Mastruzzi (2010), The worldwide governance indicators: Methodology and analytical issues, The World Bank.

Marques, A.C., J.A. Fuinhas and J.R. Pires Manso (2010), 'Motivations driving renewable energy in European countries: A panel data approach', Energy Policy, 38:11, 6877-6885.

Meier, P., M. Vagliasindi and M. Imran (2014), The design and sustainability of renewable energy incentives: An economic analysis, The World Bank, New York, p. 255.

Mundlak, Y. (1978), 'On the pooling of time series and cross section data', Econometrica, 46:1, 69-85.

Popp, D., I. Hascic and N. Medhi (2011), 'Technology and the diffusion of renewable energy', Energy Economics, 33:4, 648-662.

Plante, M. (2014), 'The long-run macroeconomic impacts of fuel subsidies', Journal of Development Economics, 107, 129-143. 
REN21 (2015), Renewables 2015 Global Status Report, www.ren21.net/status-ofrenewables/global-status-report, accessed 5 June 2016.

Sadorsky, P. (2009a), 'Renewable energy consumption and income in emerging economies', Energy Policy, 37:10, 4021-4028.

Sadorsky, P. (2009b), 'Renewable energy consumption, CO2 emissions and oil prices in the G7 countries', Energy Economics, 31:3, 456-462.

Schmidt, T.S., R. Born and M. Schneider (2012), 'Assessing the costs of photovoltaic and wind power in six developing countries', Nature Climate Change, 2:7, 548-553.

Schunck, R. (2013), 'Within and between estimates in random-effects models: Advantages and drawbacks of correlated random effects and hybrid models', The Stata Journal, 13:1, 6576.

Stadelmann, M. and P. Castro (2014), 'Climate policy innovation in the South - Domestic and international determinants of renewable energy policies in developing and emerging countries', Global Environmental Change, 29, 413-423.

Teorell, J., S. Dahlberg, S. Holmberg, B. Rothstein, A. Khomenko and R. Svensson (2016), QoG Standard Dataset 2016, version Jan16, The Quality of Government Institute, University of Gothenburg, http://www.qog.pol.gu.se, accessed 29 January 2016.

The Guardian (2016), 'Slump in oil prices drives green energy takeup in top exporting nations', www.theguardian.com/environment/2016/jan/20/slump-in-oil-prices-drives-green-energytake-up-in-top-exporting-nations, accessed 26 April 2016.

United States Energy Information Agency (2016), International energy statistics, www.eia.gov/cfapps/ipdbproject/IEDIndex3.cfm?tid=2\&pid=2\&aid=12, accessed 29 September 2016. 
Whitley, S. (2013), At cross-purposes: subsidies and climate compatible investment, Overseas Development Institute (ODI), London, www.odi.org.uk/publications/7343-subsidiesclimate-compatible-investment-fossil-fuel-private-finance, accessed 15 June 2016.

World Bank (2016), World development indicators, http://databank.worldbank.org/data/reports.aspx?source=world-development-indicators, accessed 29 April 2016. 